\title{
JARINGAN KULINER KOTA DI KEBON SIRIH
}

\author{
Andreas Tanuwijaya ${ }^{1)}$, Dewi Ratnaningrum ${ }^{2)}$ \\ 1) Program Studi S1 Arsitektur, Fakultas Teknik, Universitas Tarumanagara, andreast018@gmail.com \\ 2) Program Studi S1 Arsitektur, Fakultas Teknik, Universitas Tarumanagara, dewitrionotasman@gmail.com
}

\begin{abstract}
Abstrak
Komunitas merupakan kelompok dari beberapa orang yang memiliki tujuan tertentu dan kegiatan yang sangat bervariatif, serta tidak terikat oleh sebuah pola kegiatan tertentu. Komunitas ini kemudian mencari tempat tersendiri untuk dijadikan tempat berkumpul atau "ruang ketiga". Ruang ketiga merupakan wadah dari para komunitas dengan keadaan bebas ekspresi dan bersifat publik. Wadah ini berada di luar pekerjaan atau rumah mereka, namun tetap merasa nyaman. Ruang ketiga mulai hilang seiring dengan perkembangan teknologi, terutama di pusat kota seperti Jakarta dengan laju pertumbuhan penduduk dan ekonomi yang sangat tinggi. Keadaan memudahkan kita untuk berinteraksi melalui teknologi yang menawarkan ruang ketiga di dunia maya sebagai tempat berkumpulnya komunitas. Salah satu ruang ketiga secara nyata yang terus ada adalah "tempat makan" terutama pada sektor informal. Jakarta Pusat menjadi letak strategis bagi pertumbuhan kuliner karena pusat perkantoran dan ekonomi berada di sana. Metode yang digunakan adalah tipologi, melihat langsung kawasan dan mengamati aktivitas serta perasaan ruang yang terjadi di sana. Salah satu kuliner yang terkenal di Jakarta Pusat adalah Kuliner Sabang yang berada di Jalan Sabang dan bersebelahan dengan perkantoran di Jalan M.H. Thamrin, Kelurahan Kebon Sirih, Kecamatan Menteng. Ditambah lagi 2 kuliner yang berdekatan dengan Kuliner Sabang, yaitu Kuliner Bank Swasta Mandiri dan Kuliner Kebon Sirih. Hal ini membuka potensi untuk menciptakan jaringan di antara sentra kuliner sehingga tercapainya tujuan "ruang makan" sebagai ruang ketiga. Jaringan Kuliner Kota (Urban Culinary Linkage) direncanakan hadir sebagai jaringan perkotaan yang memperkuat karakteristik kuliner di kawasan Sabang dan menjadi ruang ketiga bagi karyawan serta warga di kelurahan Kebon Sirih.
\end{abstract}

Kata kunci: jaringan; kota; kuliner; pusat

\begin{abstract}
Community is a group of several people who have specific goal and activities that are very varied, and are not in accordance with certain pattern of activity. They will look for a place for them to gathering or we call it "third place". The third place is a public place that the people inside can act freely. This place is outside from their work or home, yet still feels comfortable. However, the third place began to disappear along with technological developments, especially in urban city such as Jakarta that have very high population and economic growth rates. This situation allows us to interact with others through technology that offers a third place in cyberspace as a gathering place. One of the third place that always continue to exist is a "dining area", particularly in the informal sector. Central of Jakarta becomes a strategic location for culinary growth because of its office and economic center. This Project is using the "typology" method, observing the activities in the area. One of the familiar culinary in Central Jakarta is Sabang culinary, located on Jalan Sabang / Jalan H. Agus Salim and next to the office buildings on Jalan M. H. Thamrin, Kebon Sirih sub district, Menteng district. There are 2 culinary adjacent to the Sabang culinary, namely Bank Mandiri culinary and Kebon Sirih culinary, a network among culinary centers and to achieve the purpose of the "place to eat" as a third place. This is where Urban Culinary Linkage (Jaringan Kuliner Kota) is planned as an urban network that renforces culinary characterictics in Sabang area and as a third place for employees and residents in Kebon Sirih sub district.
\end{abstract}

Keywords: center; city; culinary; linkage 


\section{PENDAHULUAN}

Montgomery, Charles (2013) menyatakan bahwa pada dasarnya sejak dahulu kala, manusia merupakan makhluk individu dan juga sosial yang artinya manusia tidak akan pernah bisa hidup sendiri. Manusia selalu ingin bergaul dan berkumpul dengan sesamanya entah itu menguntungkan ataupun tidak. Hal inilah yang menyebabkan munculnya suatu komunitas ketika beberapa orang berkumpul, keadaan ini bisa terjadi dengan siapa saja dan di lingkungan manapun. Komunitas ini kemudian memiliki tujuan tertentu dan kegiatan yang sangat bervariatif, serta tidak terikat oleh sebuah pola kegiatan tertentu. Komunitas yang terbentuk kemudian mencari tempat tersendiri untuk dijadikan "basecamp" atau tempat yang sehari-hari digunakan untuk berkumpul (third place).

Third Place merupakan wadah dari para komunitas dengan keadaan bebas ekspresi dan bersifat publik. Wadah ini muncul ketika beberapa orang berkumpul melakukan suatu kegiatan untuk jangka waktu dan tempat tertentu yang tempatnya berada di luar dari pekerjaan atau rumah mereka, namun tetap merasa nyaman. Kota-kota besar seperti Jakarta memiliki laju pertumbuhan penduduk dan ekonomi yang sangat tinggi. Hal ini menciptakan tingkat mobilitas dan intensitas pekerjaan naik dengan sangat pesat dan menyebabkan ruang interaksi sosial menjadi berkurang. Seiring perkembangan jaman, teknologi memudahkan kita untuk berinteraksi terhadap sesama. Teknologi menawarkan "third place" di dunia maya sebagai tempat berkumpulnya komunitas dengan tidak memerlukan mobilitas, third place secara nyata di perkotaanpun kemudian menjadi hilang. Salah satu third place yang terus ada adalah "tempat makan" baik di sektor formal maupun informal. Faktanya, banyak orang ke tempat makan lebih dari sekedar makan, melainkan menciptakan suatu hubungan yang lebih erat. Percakapan yang terjadi saat makan merupakan salah satu faktor berkembangnya komunitas. Psikologi dalam diri kita saat makan makanan yang sama dengan orang lain di sekitar kita memberi kesan bahwa kita bersedia untuk bekerja sama dan mempercayai satu sama lain.

Di Jakarta, sektor informal berupa pedagang kaki lima mulai mendominasi jalan pada tahun 1998 dengan tujuan membantu pertumbuhan ekonomi di Jakarta dimana pertumbuhan ekonomi pada saat itu sedang tidak stabil. Walaupun demikian, sektor informal yang padat dan liar seringkali ditentang oleh penataan kota karena masalah yang ditimbulkannya seperti kemacetan dan visual yang kurang enak dipandang dalam segi perkotaan. Namun, visual, tipologi, serta rasa makanan tertentu inilah yang menjadi identitas di satu kawasan yang kemudian menjadi area kuliner di kawasan tersebut. Jakarta Pusat menjadi letak strategis bagi pertumbuhan kuliner karena pusat perkantoran dan ekonomi berada di sana. Salah satu kuliner yang terkenal di Jakarta Pusat adalah Kuliner Sabang yang berada di Jalan Sabang / Jalan H. Agus Salim dan bersebelahan dengan perkantoran di Jalan M.H. Thamrin, Kelurahan Kebon Sirih, Kecamatan Menteng. Kuliner ini identik dengan pedagang kaki lima yang memiliki berbagai rasa makanan dan minuman khas Indonesia sepanjang jalannya, namun kuliner ini masih bersifat liar atau belum dibina oleh pemerintah. Ditambah lagi 2 kuliner yang berdampingan dengan Kuliner Sabang, yaitu Kuliner Bank Swasta Mandiri dan Kuliner Kebon Sirih yang sudah dibina oleh pemerintah. Ke-3 kuliner ini membuka potensi sebagai identitas utama yang dimiliki oleh Kelurahan Kebon Sirih dengan pengunjung yang bersifat perkotaan.

Disinilah, Jaringan Kuliner Kota (Urban Culinary Linkage) direncanakan hadir sebagai jaringan dan perantara dari ke-3 kuliner ini, serta menjadi wadah bagi aktivitas warga dan karyawan-karyawan dari perkantoran yang belum terpenuhi. Urban Culinary Linkage sebagai third place juga turut menjadi tempat pemberhentian sementara dalam segi perkotaan karena letaknya yang berdekatan dengan titik transportasi umum.

\section{KAJIAN LITERATUR}

Menurut Ray Oldenburg (1997) dalam bukunya yang berjudul "The Great Good Place", suatu tempat dapat dikatakan sebagai ruang ketiga apabila memiliki karakteristik seperti netral, setara terhadap sesama, percakapan merupakan aktivitas utama, aksesibilitas dan akomodasi yang mudah dijangkau, pengunjung yang tetap, bangunan yang "rendah hati", dan 
juga suasana bangunan bersifat "ceria", serta terasa seperti rumah kedua bagi pengunjungnya.

Menurut McLaren, Duncan dan Agyeman, Julian (2015), sharing cities sama seperti sustainabilities. Sustainabilities bukan hanya lingkungan yang hijau, tapi juga yang sangat berpengaruh adalah sustainable society yang berhubungan juga dengan sistem ekonomi. Manusia merupakan natural sharers yang bisa dilakukan dimana saja, tapi karena komersialisasi dari dunia modern inilah yang menghilangkan identitas manusia. Kemudian munculah istilah "sharing economy place" dimana tempat-tempat tertentu sifatnya berbayar (komersial) atau lebih privat, bukan lagi public. Perkembangan jaman seperti teknologi tidak dapat dihindari, namun hal ini juga dapat menimbulkan peluang antara urban space dengan cyberspace.

Menurut Montgomery, Charles (2013), tingkat kebahagiaan suatu kota dipengaruhi oleh beberapa ide. Ide tersebut adalah kota satelit yang seharusnya memiliki tingkat kebahagiaan yang lebih tinggi, meniadakan kendaraan bermotor roda 4 dapat menciptakan public space tetap menarik, taman yang kecil namun ramai dan berbeda-beda jenis tanamannya membuat pengunjungnya lebih bahagia, mobilitas yang cepat dan nyaman, sumber daya yang cukup dan tersebar.

Menurut Lerner, Jaime (2014), layaknya seberapa bagus obat dalam akupuntur mengobati satu titik di dalam tubuh pasien, perencanaan kota yang sukses juga dipengaruhi oleh respon kehidupan kotanya beserta reaksi berantai yang positif bermula di satu kawasan. Urban acupuncture sebenarnya adalah suatu gagasan di tempat tertentu yang memberikan dampak besar kepada lingkungan sekitarnya.

Menurut Tichelaar, Esti (2015), street vending / street vendor termasuk ke dalam sektor informal di dalam penataan urban informality yang memiliki 2 sistem, formal and informal economy system. Street vending ikut ambil peran dalam pertumbuhan ekonomi Jakarta, namun juga bisa menjadi elemen yang menyebabkan hilangnya public space.

\section{METODE}

Metode pembahasan dilakukan secara deskriptif kualitatif terkait dengan kondisi kawasan terpilih yang terkait dengan segi arsitektural. Adapun cara yang dilakukan untuk mengumpulkan data, yaitu observasi dan juga empiris. Observasi bertujuan untuk mengamati keadaan sekitar dari kegiatan yang ada, kemudian akan dijadikan data. Sedangkan, empiris bertujuan untuk mendukung data yang dikumpulkan lewat observasi tadi dengan cara memahami user melalui wawancara. Terdapat 2 metode perancangan yang digunakan, antara lain:

\section{a. Tipologi}

Merupakan kajian tentang tipe. Metode ini digunakan untuk mengamati kegiatan / kebiasaan dari user di kawasan terkait secara rinci demi menyelesaikan masalah arsitektural. Tipe mengandung bentuk dasar dari kebiasaan tersebut yang berkembang menjadi model tertentu. Tipologi dalam arsitektur melihat objek dan proses sekaligus. Objek dan proses yang dimaksud bisa dari user ataupun bangunan yang ada di kawasan terkait. Proses dari user itu sendiri bisa merupakan bagaimana cara mereka berpindah dari satu tempat ke tempat yang lainnya, cara mereka berinteraksi, dan lain-lain.

\section{b. Arkitipe Keruangan (Spatial Archetype)}

Metode ini berada dalam penyelidikan ilmu jiwa dan sangat berkaitan dengan ingatan kolektif. Dalam konteks kota, ingatan kolektif warga adalah unsur-unsur di dalam peristiwa tertentu. Ingatan kolektif ini berada di alam bawah sadar manusia yang nantinya akan muncul ke tingkat permukaan kesadaran manusia. Hal inilah yang menentukan tindakan manusia dalam menentukan wujud batas ruangnya. Dengan mengetahui arkitipe keruangan, diharapkan supaya perancang lebih mendalami dan merasakan batas-batas dari aktivitas di kawasan terkait. 


\section{DISKUSI DAN HASIL}

Berikut merupakan keadaan tapak setelah dilakukan beberapa analisa:

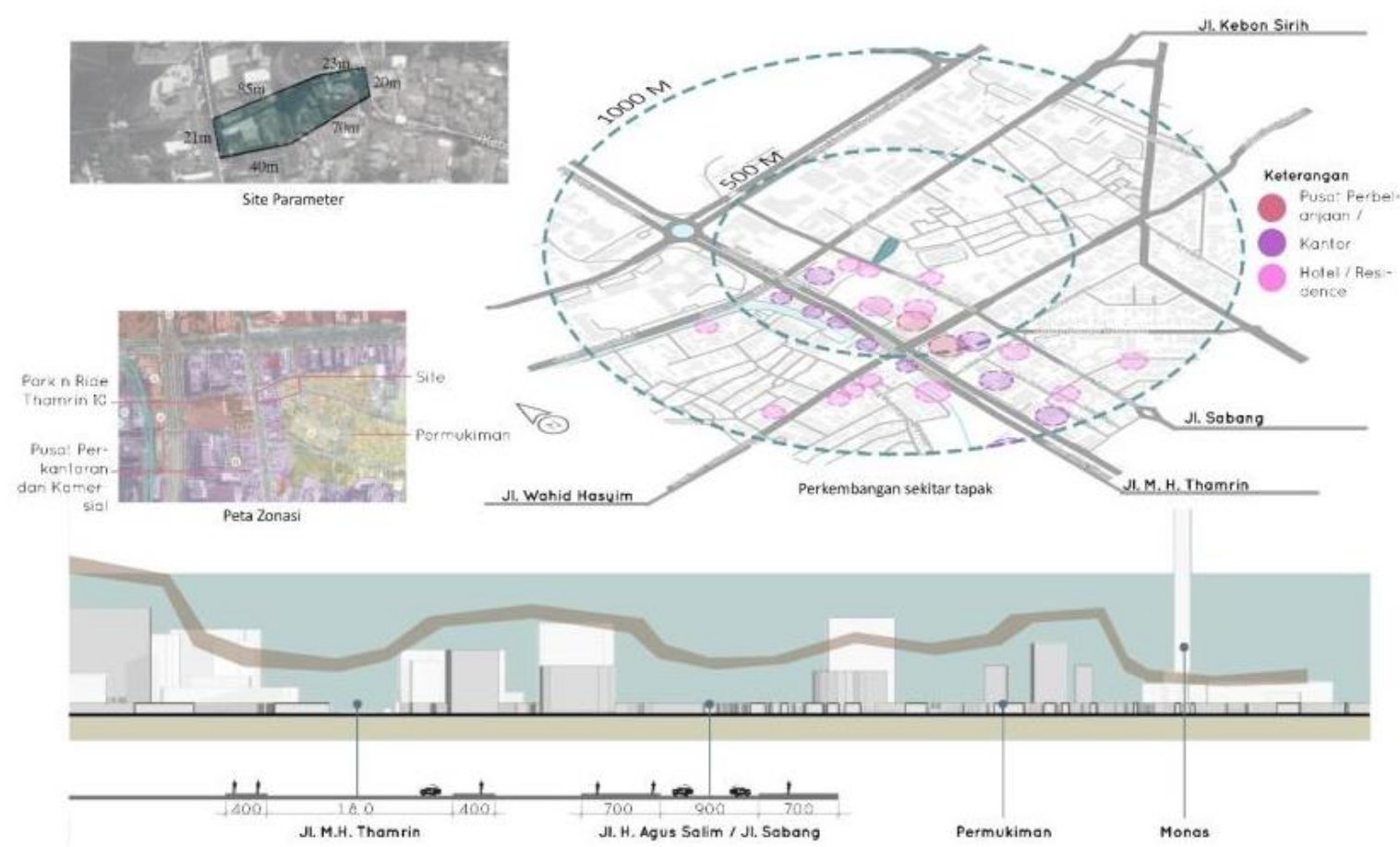

Gambar 1. Site Overview / Ringkasan Tapak

Sumber: Penulis, 2019

Tapak berada di kawasan Jalan Sabang yang sangat terkait dengan pusat bisnis dan perkantoran dimana di samping perkantoran tersebut terdapat pedagang kaki lima yang selalu ada untuk memenuhi kebutuhan makan para karyawan. Namun, jumlah perkantoran dengan rekreasi tidak sebanding sehingga para karyawan membutuhkan tempat yang lebih tenang dan rileks daripada kantor. Keterangan Tapak; Zona: Perkantoran dan Jasa, Campuran; KDB: 55\%; KB: 8; KTB: 55\%; KLB: 3; KDH: 30\%; Luas Tapak: 2800 m² $^{2}$

Terbentuklah program berdasarkan analisa tapak dan konsep kuliner serta visi misi yang dituangkan ke dalam proyek: 


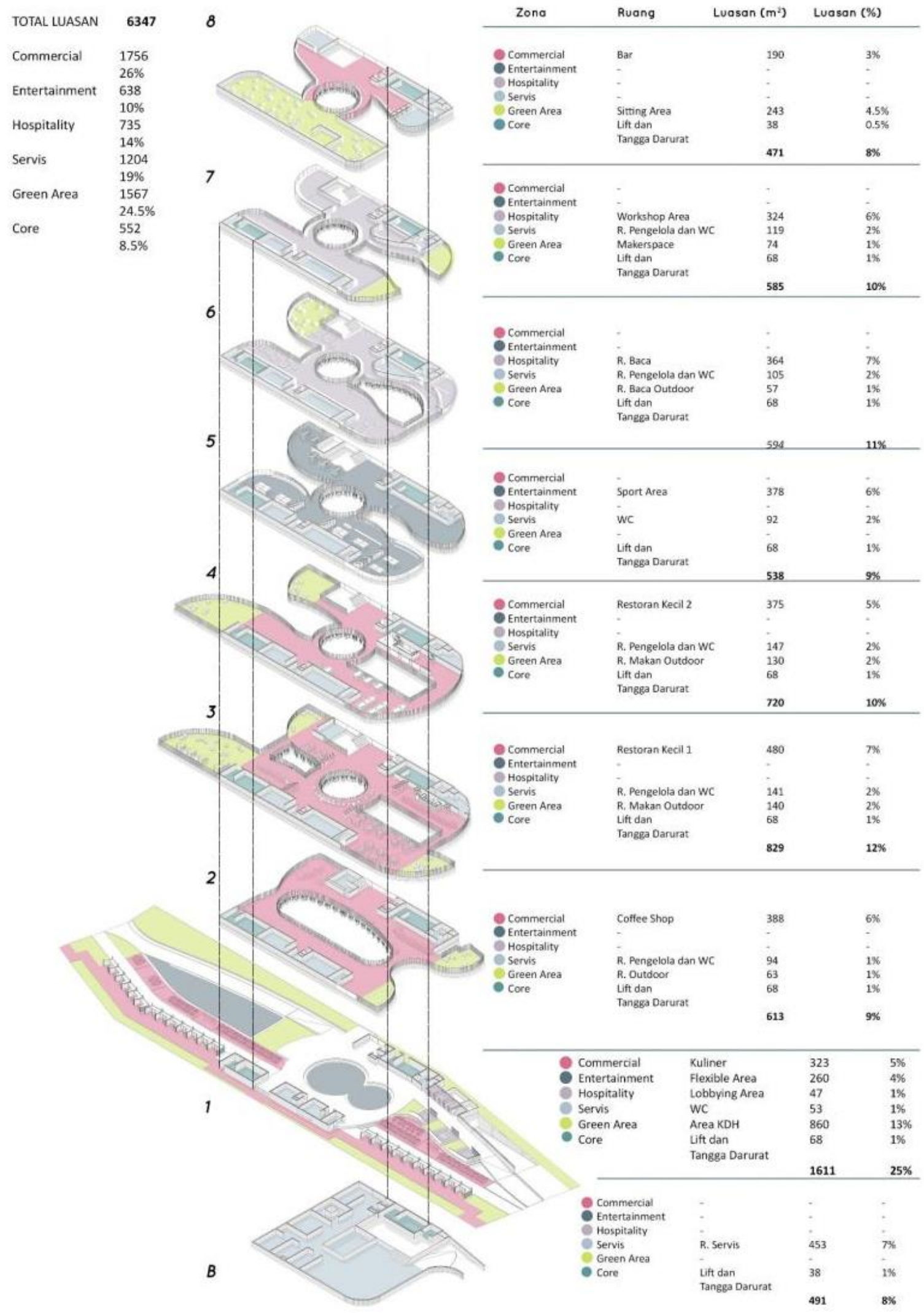

Gambar 2. Programatik

Sumber: Penulis, 2019 
Terbentuklah konsep proyek berdasarkan analisa dan karakteristik dari kawasan Sabang tersebut:
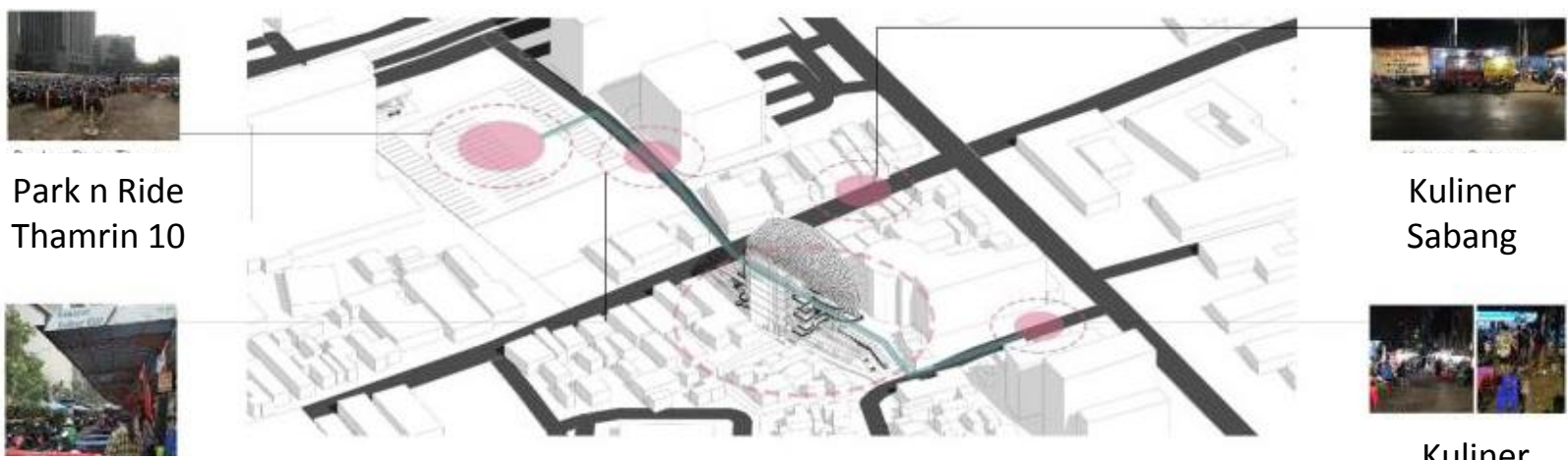

Kuliner

Sabang

Kuliner

BSM

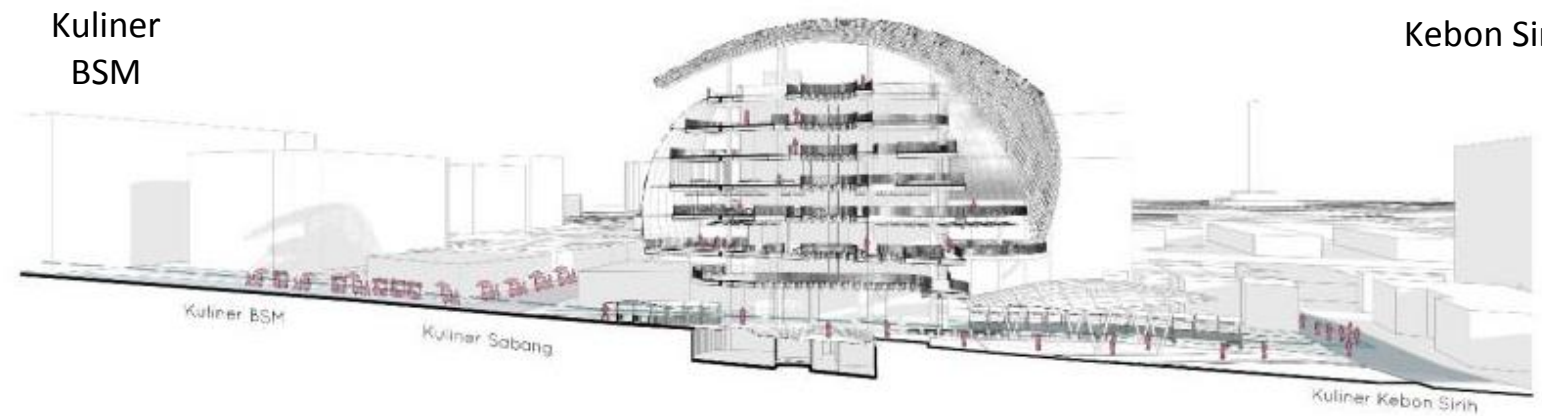

Kuliner

Gambar 3. Jaringan Kuliner

Sumber: Penulis, 2019

Keberadaan proyek dimaksudkan menjadi penghubung antar 3 kuliner di Kebon Sirih, yaitu kuliner Bank Swasta Mandiri, Kuliner Sabang, dan kuliner Kebon Sirih, serta sebagai pusat kegiatan karyawan dan warga Kebon Sirih. Kuliner BSM berada di Jl. Kampung Lima bersebelahan dengan Park $n$ Ride Thamrin 10 dengan tujuan menunjang karyawan dalam segi fasilitas makanan yang terjangkau. Kuliner Sabang merupakan pedagang kaki lima yang berada di sepanjang Jalan Sabang dengan status liar. Pengunjungnya karyawan untuk kebutuhan kerja seperti meeting informal dan networking dan juga dari luar kawasan Sabang dengan jumlah 34 kios dan jam operasional 09.00 - 02.00. Kuliner Kebon Sirih merupakan kuliner turun menurun oleh warga Kebon Sirih dan sudah dibina oleh UMKM, serta turut memeriahkan area kuliner dengan adanya komunitas musik. 


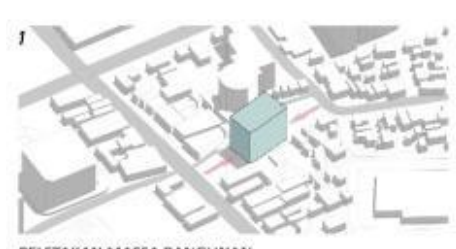

PELETAKan MASSA BANGUNAN

setback bangunan ke bagian tengah tapak, menciptakan 3 raryaman die dalam bangunan
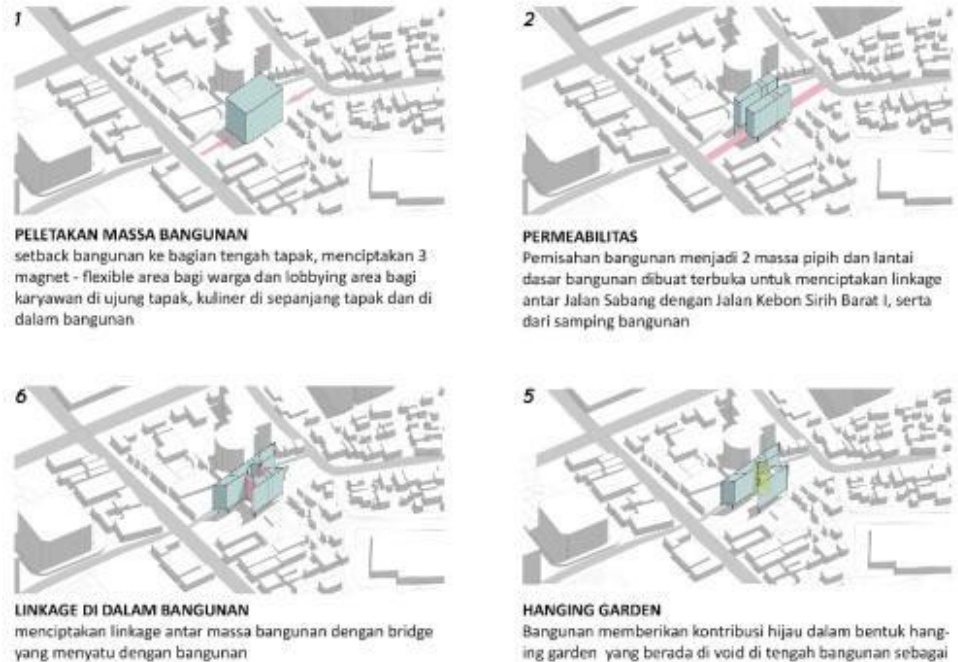
PERMEABILTAS Pemisahan bangunan menjadi 2 massa pipih dan lantal dasar bangunar dibuat terbuka untuk menciptakan linkage

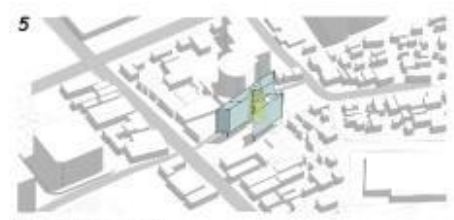

HANGING GARDEN

Bangunan memberikan kontribusi hijau dalam bentuk hane. ing garden vang berada di woid di tengah bangunan sebagai titik pusat pengunjung

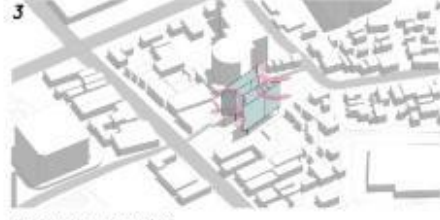

\section{BENTUK FUUID MASS}

Ujang bangunan dibuat melingkar ke dalam untuk membe

ung dari lear ke dalam

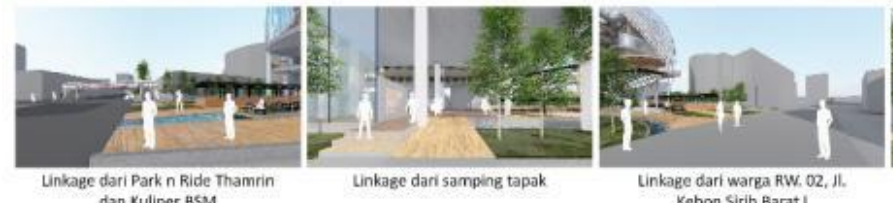

Gambar 4. Skema Desain

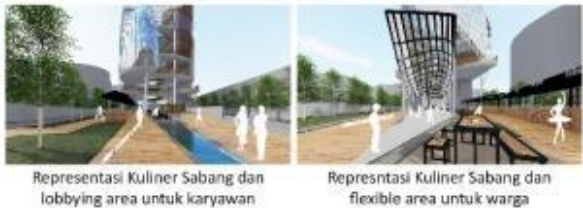

Representasi Kuliner Sabang dan Represntasi Kuliner Sabang dan

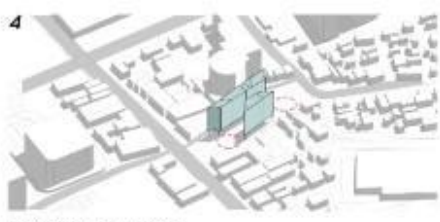

ZONING AREA FLEKSIBEL

di setback lebin jauh ke arah tengah dan yan lainya di setback keluar untuk menciptakan ruarg fleksibel yang berada lebih ke dalam bangunar

Sumber: Penulis, 2019

Proses desain selama studio berlangsung, berawal dari rasa kontekstual terhadap tapak dan mengambil tipologi jalan (street) sebagai representasi dari kuliner jalanan, serta sifat permeabilitas (gambar 4) dan proyek memiliki tema yang bervariatif per lantai (gambar 5).

\section{Gambar 5. Design Theme}

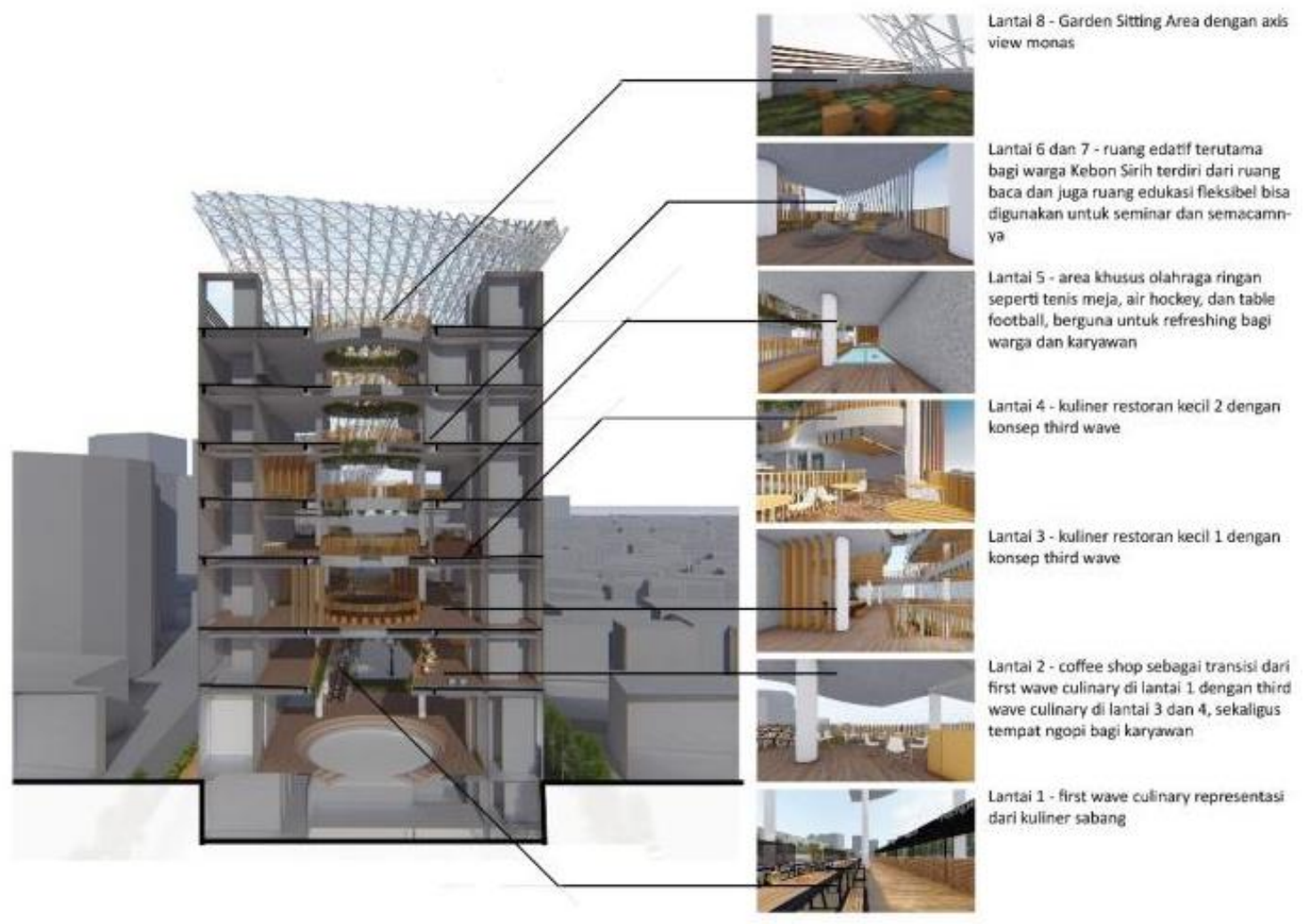

Sumber: Penulis, 2019 


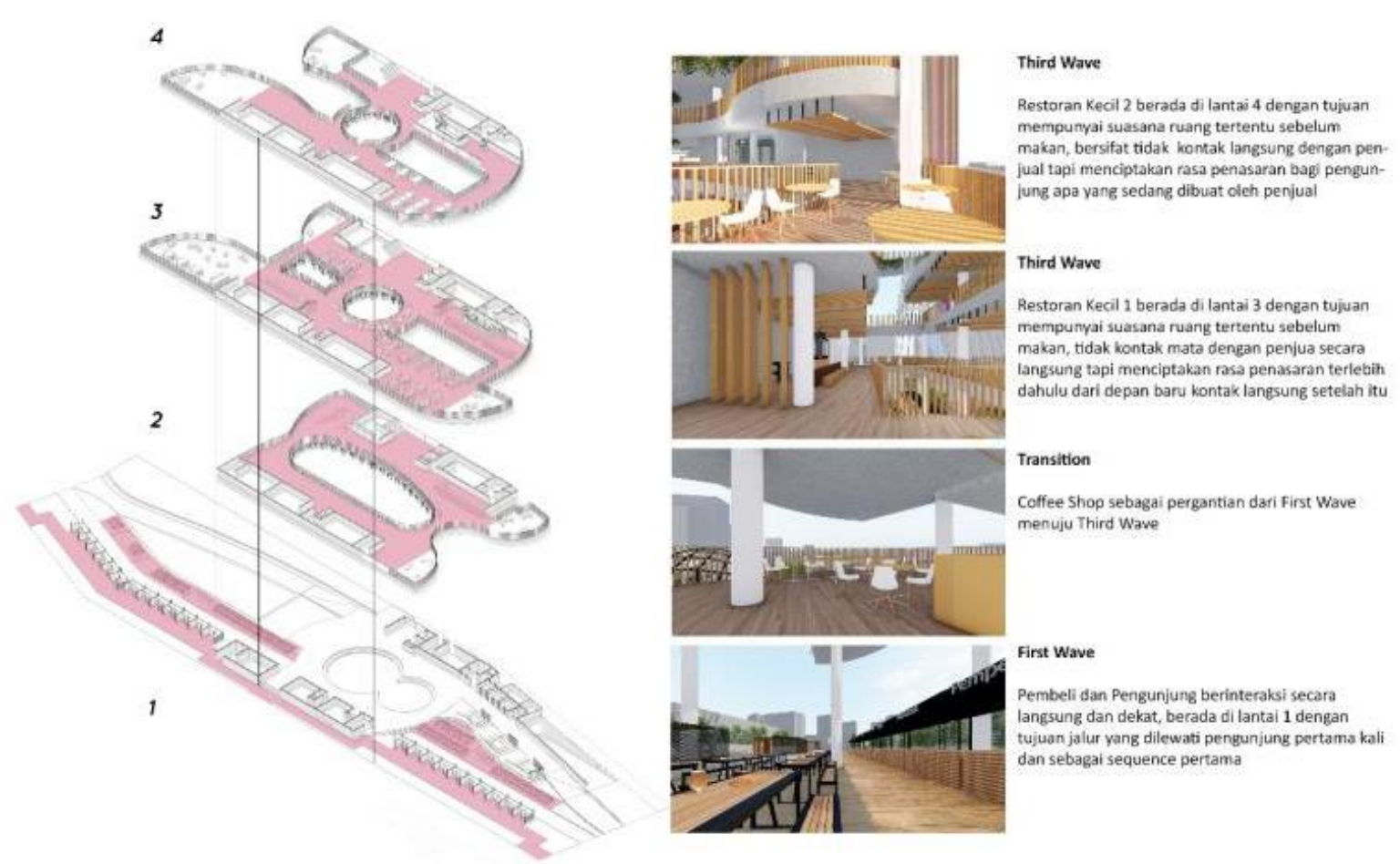

Gambar 6. Gelombang Kuliner Sumber: Penulis, 2019

Kuliner terbagi menjadi 3 gelombang: gelombang 1 yang berarti penjual dan pembeli kontak langsung secara disengaja maupun tidak disengaja karena keberadaan penjual berada di tempat yang sering dilalui oleh pembeli, seperti di jalan raya. Gelombang kedua adalah penjual secara massal dipadatkan di satu tempat lalu pembeli datang kesana. Dan gelombang ketiga, dimana penjual berada di suatu tempat terpencil namun memiliki nama (brand) yang terdengar sampai cukup jauh, biasanya berupa satu toko yang berada di dalam lingkungan yang lebih kecil seperti komplek sehingga menciptakan rasa penasaran terhadap pembeli walaupun letaknya tersebunyi. Toko ini juga bersifat lebih ramah dan nyaman karena letaknya yang jauh dari aktivitas pusat kota. 


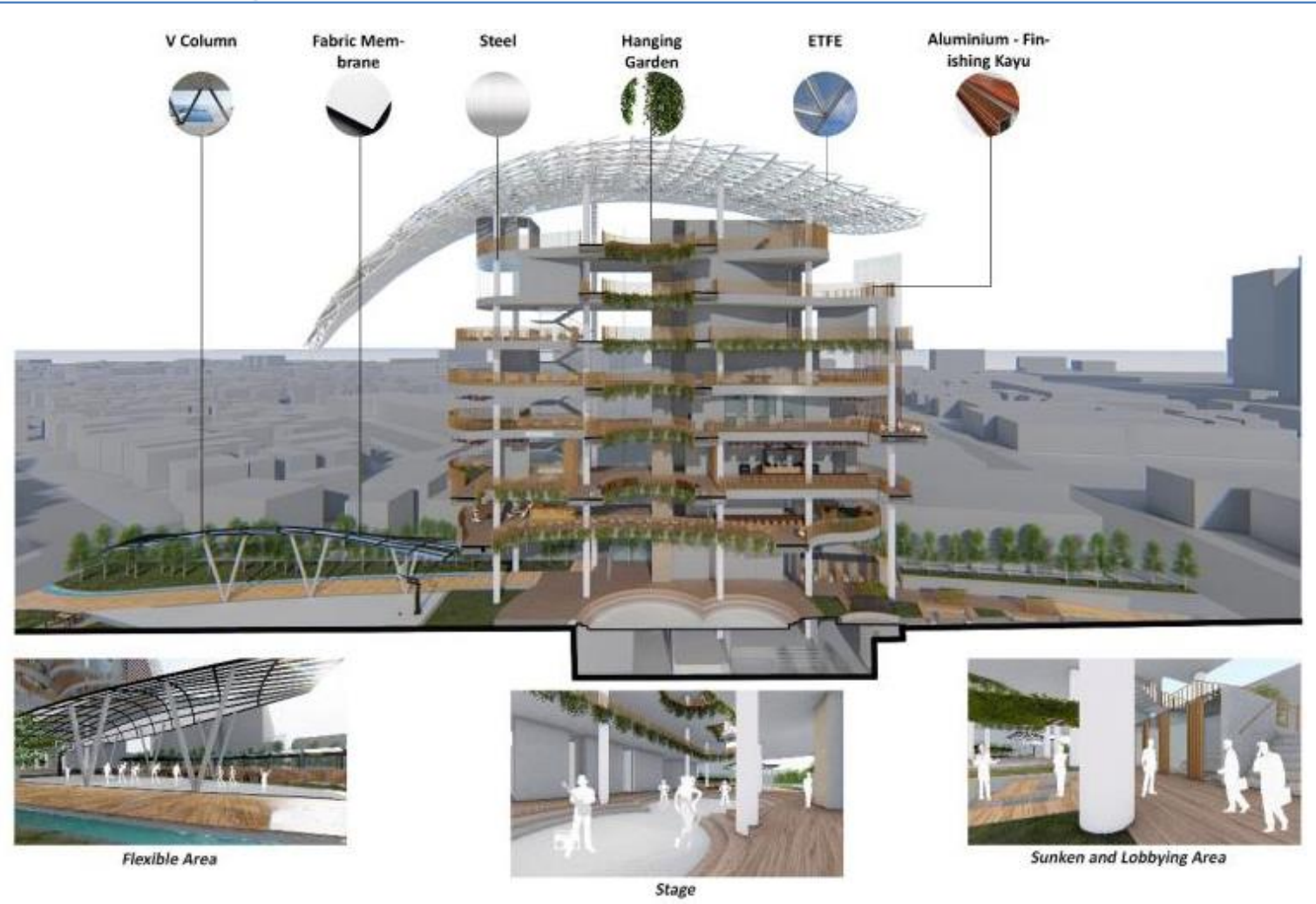

Gambar 7. Potongan Perspektif

Sumber: Penulis, 2019

Material yang digunakan mayoritas menggunakan kayu dan baja sebagai rangkanya. Dimaksudkan supaya lebih ramah terhadap pengunjung dan lebih ringan, serta pemakaian kaca pada fasad tidak seluruhnya tertutup dan railing bertujuan supaya bangunan terkesan lebih terbuka.

\section{KESIMPULAN DAN SARAN}

Dari kajian di atas, dapat terbilang kalau third place merupakan salah satu ruang yang penting demi sebuah kota, komunitas, dan juga individu masing-masing. Ciri utama dari third place yaitu:

- Openness yang bersifat inklusif dimana siapapun bisa datang kapan saja dan menjadi pribadi yang baru (heterogen). Aktivitas utama yang terjadi adalah pertukaran informasi lewat percakapan baik individu maupun komunitas (pengunjung tetap)

- Contextuality yang artinya memiliki identitas dari keadaan lokal dan dapat menjawab kebutuhan setiap individu yang berbeda-beda.

- Flexibility yang aktivitasnya dapat beradaptasi sesuai kebutuhan dari kebebasan usernya dan sangat bervariatif sehingga menciptakan suasana yang ceria bagi setiap individu.

Salah satu lokasi yang memiliki potensi untuk mencerminkan karakteristik tersebut adalah Kawasan Kelurahan Sirih yang dibagi menjadi Kawasan Sabang dan Kawasan Kebon Sirih itu sendiri, berada di Jakarta Pusat dimana pertumbuhan ekonomi dan teknologi sangatlah pesat. Hal ini juga menciptakan kesenjangan sosial antar sektor formal dengan informal terutama pedagang kaki lima, namun dalam sisi lain kedua sektor ini saling membutuhkan dan saling terikat. Berdasarkan data dan analisis yang sudah dijabarkan di atas, terdapat beberapa masalah dan kebutuhan yang berada di Kawasan ini antara lain, street vendor memiliki peran yang penting dalam kehidupan sosial, keadaan infrastruktur seperti jalan pedestrian dan area open space sangat berpengaruh ke keadaan psikologis manusia dalam taraf kebahagiaan, Jalan 
Sabang akan berkembang menjadi kawasan mid-rise yang akan menimbulkan semakin banyaknya tuntutan akan kebutuhan fasilitas rekreasi dan juga makanan.

Untuk menutupi semua masalah dan kebutuhan yang ada, Kebon Sirih Urban Point hadir sebagai third place penghubung jaringan network dan infrastruktur, penambahan fasilitas yang dibutuhkan dengan menambahkan program-program dengan kompleksitas tinggi, serta menumbuhkan rasa sosial bagi kawasan tersebut dan diharapkan dapat memberikan dampak positif bagi sekitar kawasan.

\section{REFERENSI}

Ahmad, R. (2018). PKL di Jalan Sabang akan Direlokasi, diunduh 04 Januari 2020, < https://akurat.co/news/id-391041-read-pkl-di-jalan-sabang-akan-direlokasi;;.

Lerner, J. (2014). Urban Acupuncture. Washington: Island Press.

McLaren, D. \& Agyemen, J. (2015). Sharing Cities: A Case for Truly Smart and Sustainable Cities. Massachusetts, Cambridge: The MIT Press.

Montgomery, C. (2013). Happy City: Transforming Our Lives Through Urban Design. Canada: Doubleday Canada.

Nursita, S. (2018). PKL di Kawasan Sabang Liar Tetapi Tak Dipermasalahkan, diunduh 03 Januari 2020, <https://megapolitan.kompas.com/read/2018/11/15/08330951/pkl-dikawasan-sabang-liar-tetapi-tak-dipermasalahkan?page=all.

Oldenburg, R. (1997). The Great Good Place. U.S: Da Capo Press.

Tichelaar, E. (2015). Integrating Jakarta's Street Vendors in Architecture. Master Thesis Research, ExploreLab 18 (2013-2015). 
